\title{
Applying Cooperative Techniques in Teaching Problem Solving
}

\section{KRISZTINA BARCZI ${ }^{1}$}

$\approx$ Teaching how to solve problems - from solving simple equations to solving difficult competition tasks - has been one of the greatest challenges for mathematics education for many years. Trying to find an effective method is an important educational task. Among others, the question arises as to whether a method in which students help each other might be useful. The present article describes part of an experiment that was designed to determine the effects of cooperative teaching techniques on the development of problem-solving skills.

Keywords: Cooperative techniques; Problem solving; Investigation; Open problem 


\section{Uporaba sodelovalnih tehnik pri poučevanju reševanja problemov}

KriszTina BARCZI

$\propto$ Poučevanje reševanja problemov - od reševanja preprostih enačb pa vse do reševanja zapletenih tekmovalnih nalog - je že več let eden izmed največjih izzivov pri pouku matematike. Iskanje učinkovite metode je pomembna izobraževalna naloga. Med drugim se postavlja vprašanje, ali je tehnika sodelovalnega učenja, pri kateri si učenci medsebojno pomagajo, lahko uporabna. Predstavljeni članek opisuje del raziskave, ki je bila zasnovana $\mathrm{z}$ namenom, da pokaže vpliv tehnik sodelovalnega poučevanja na razvoj spretnosti reševanja problemov.

Ključne besede: sodelovalne tehnike, reševanje problemov, raziskovanje, odprt problem 


\section{Introduction}

Teaching problem solving is one of the most important aims of mathematics education. The reason for this is that problem solving develops cognitive abilities, emphasises the application of mathematical knowledge, improves creativity, etc. (Schoenfeld, 1992), while also being a basic skill that is needed in all areas of life (Kirkley, 2003). In Hungary, mathematical problem solving has a strong tradition, but mainly for gifted students; for students of average ability, there are currently some issues regarding the teaching of problem solving. The first and most widespread method is front teaching. Due to the fact that class sizes in many schools are quite large (approximately 30 students), this method is not the most effective in some situations. There is no doubt that, when teaching problem solving, a kind of dialogue needs to be present between the teacher and the students. This enables the teacher to simultaneously guide the children towards both the right solution and the right way of thinking. If the teacher asks the whole class questions, there are usually only a small number of students who take part in the dialogue actively, students who understand what is going on and would probably be able to solve the tasks on their own. What about the others? Some students will listen in silence and try to follow the discussion, while others will copy everything from the board but not necessary understand it. It is precisely this situation that gave rise to the idea of using cooperative teaching. Moreover, the problem collections used in class contain hardly any open problems and lack investigations. Many tasks can be solved simply by following "recipes", algorithms. The problems that are closest to the open problem type are those involving geometric constructions or parametric equations, as well as those that provide an opportunity for discussing multiple solutions. These rarely appear in lessons but are frequently present in mathematics study sessions and among mathematics competition problems.

In order to try to improve this situation, an experiment was planned and carried out that was designed to determine the effects of the regular use of cooperative teaching techniques on the development of students' problem solving skills, and to provide improved insight into how students solve problems. The article presents a part of this experiment.

\section{Theoretical Background}

\section{Problem solving}

Problems - A problem is a task in which we attempt to find a solution on the basis of certain known data and conditions. First of all, we need to 
distinguish between routine and non-routine problems. Routine problems are those in which the problem solver immediately knows and recognises the correct process for the solution, whereas in non-routine problems the solver does not identify how to solve the problem immediately (Mayer \& Hegarty, 1996). Of course, the final goal is to find the solution, but this is often impeded by various obstacles that depend on many factors, such as the problem solver's age, ability, etc. How to recognise and overcome these obstacles is not always obvious. According to Fisher (2005), the following elements are required to define what a problem is: (1) what is given, (2) obstacles, (3) aims and (4) effort. Another description of a problem is provided by Lénárd (1987), who says that a problem is a situation where we want to reach a specific goal, but the way of reaching this goal is hidden. Pólya (1962) describes problems similarly, stating that if we have a problem it means that we are trying to find some means with the help of which we can reach a clearly stated but not necessary easily achieved aim. All of these definitions regard problem as a rather broad concept, and they agree that in problem solving we know where to start and in most cases we know where we want to end up, but the "HOW" is as yet unknown to the problem solver.

Open problems - Open problems are problems (1) that are unsolved, or (2) whose solution depends on the interpretation of the problem solver, or (3) where multiple ways of solving the problem are possible, or (4) that suggest further questions and possible generalisations (Ambrus, 2000). Investigations, real-life situations, projects or problem fields are considered to be open problems according to Pehkonen (1999), who says that open-ended tasks can be created by problem posing, problem variations or by working with problem fields. The problem presented in the present article belongs to (3) and (4). The main benefits of using open mathematical problems are that they provide an opportunity for children with different mathematical abilities to experience success, they allow students to progress at their own pace, and with multiple solutions they provide an excellent basis for mathematical discussions (Way, 2013). Solving open problems can increase students' need to prove and justify ideas that arise during problem solving, enabling them to return to the original problem and investigate it from a different perspective, thus creating kind of a problem solving cycle (Hähkiöniemi, Leppäaho, \& Francisco, 2012).

When teaching problem solving, it is good to let students try to have their own experiences with the task at hand, encouraging them not only to solve the problem but also to formulate and find new problems (Zimmermann, 1986), since formulating problems plays a vital role in problem solving. Clearly, the easiest way to start is by using already existing problems. One option for making new tasks is to look back at a previously solved problem. Here, the solution may 
suggest new problems, or we can verify whether changing the conditions of the original problem results in something new. Another way of posing new problems from old ones arises when we have not found the solution. In this case, the problem solver usually breaks the original task up into smaller parts and attempts to solve these new, probably easier problems (Kilpatrick, 1987; Pólya, 1973).

\section{Problem solving phases}

In his renowned book How to Solve It (1973), Pólya distinguishes between the following four phases of problem solving: (1) Understand the problem: we have to understand the given information and we need to see where we want to get; (2) Make a plan: we need to determine how the given information can be connected to what we are looking for, and we need to decide which tools to use in order to obtain a solution; (3) Carry out the plan: we need to do what we have planned; and (4) Look back: this phase is more than just checking whether the answer is correct, we need to review how we solved the problem and discuss the difficulties we had to face, the ideas that helped us carry on, etc.

Schoenfeld suggests similar steps in problem solving, which are extended versions of Pólya's phases (Ambrus, 2004).

\section{Cooperative teaching and learning}

Cooperative learning is a teaching arrangement whereby people work together in order to achieve a common goal, which often means solving a problem. During this work, group members depend on each other, and the success of the team depends on their ability to cooperate. They must support each other, trust each other and respect each other if they want to overcome the difficulties that might hinder them (Kagan, 2004).

In Hungarian education, cooperative learning appeared as a result of the work of József Benda. He believed that cooperative learning could bring about a positive change in the way Hungarian schools worked, resulting in improved achievement, integration and development of students (Józsa \& Székely, 2004).

It is important to note that cooperative learning is not simple group work. According to Johnson and Johnson (1994) and Kagan (2004), in cooperative learning the following four principles should always be present: positive interdependence, individual accountability, equal participation and simultaneous interactions (PIES). Furthermore, for effective work, team members should possess social skills that they can apply appropriately. If necessary, these skills should be taught to students in advance (Johnson \& Johnson, 2009).

As for the ideal group size, Crabill (1990) recommends groups of four. The reason for this is that, in a group of four, two simultaneous dialogues can 
coexist and an ideal seating arrangement can easily be achieved, whereas groups with more members are more likely to become passive.

\section{Examples of cooperative structures}

In this section, we present some examples of cooperative structures that have been found useful and are efficiently applicable in mathematics classes. The structures were given catchy, easy-to-remember names so that students and teachers can remember them more easily, thus creating an opportunity to use the same structure in many different contexts (Kagan, 2003).

Pairs Check: In this structure, two students work together. One is the "coach" and only checks the work of the other student, or, if necessary, offers advice on how to carry on. The second student has to write everything down while explaining aloud what s/he is doing. (Kagan \& Kagan, 1998).

Jigsaw Expert Groups: The main idea of this structure is that every group is an expert in a topic or a task. They are given some time to prepare - either to collect ideas or solve a task - then new groups are formed such that each new group contains one person from each of the original groups. The new groups consequently contain students who are experts in each task. In the new groups, students share their topics with each other, notes are taken and comments are discussed (Kagan \& Kagan, 1998).

Gallery Walk: Students have to collect information or solve a task in groups of four. The information gathered is written on a poster that is displayed in the classroom. Everybody then walks around so that they can check the work of the different groups. The mingling students are allowed to write comments or ideas on each other's posters (Kagan, 2004).

\section{The teacher's role in cooperative learning}

Obviously, when using cooperative teaching techniques it is not only the classroom setting and the students' role that change, but also the teacher's role. The teacher is transformed from an instructor to a tutor, someone who guides students in the teaching/learning situation. While the students work cooperatively, the teacher's task in class is to monitor and observe their work, ensuring that they make progress, helping them if they are stuck on a problem and cannot continue alone, and providing extension exercises for groups that finish sooner (Burns, 1990). The teacher should still be the leader and, in addition to explaining the guidelines of cooperative work, it is his/her responsibility to maintain a suitable working environment. In cooperative class work, students are supposed to talk to each other, so the classroom becomes noisy, but the teacher should prevent the classroom turning into a chaotic environment (Dees, 1990). 


\section{Research question}

How does the regular use of cooperative teaching techniques contribute to effective teaching and learning of problem-solving skills?

\section{Research Methodology}

\section{Background information}

The experiment was action research, which means that the researcher was also the teacher of the class. This type of experiment has become popular amongst practitioners who would like to carry out research related to professional development. Koshy (2005) defines action research as a kind of enquiry whose aim is to constantly refine practice and ultimately contribute to the teacher's professional development. The writer states that action research means researching one's own practice, and is therefore participatory and situation-based, as well as being emergent and focused primarily on improvement. Action research is a useful tool for narrowing the gap between the goals of mathematics educators and teachers (Zimmermann, 2009).

Since the researcher was interested in the effects of cooperative techniques on the development of students' problem-solving skills, the question of using control groups arises. According to Slavin (1996), however, when comparing the outcomes of cooperative teaching and learning to other programmes, there are many factors that differ between the two alternative programmes, such as the subjects, the duration, etc., and these factors can account for the differences in the outcomes.

The school where the experiment took place is a mixed comprehensive secondary school whose strength lies in scientific subjects and computer science. The students taking part in the action research were 16-17 years old. All of the 16 participants were attending a class that prepares students for tertiary education in technology and specialises in foreign languages. Following a preparatory year, these students have four years to complete their secondary school studies. As mentioned above, the writer of the present article was the teacher of this group. The 2012/2013 academic year was the students' third year at our school. In their first year, the students attended three mathematics lessons per week, increasing to four in the subsequent two years. In the year in question, they followed the year 10 scheme of work for secondary school students. Since they had more mathematics lessons than a "normal" class, we often had an opportunity to discuss a topic in more detail or to solve problems from mathematics competitions. These students are not necessary gifted in mathematics, but the majority of them certainly have a great interest in mathematics and 
other scientific subjects. Their mathematics grades were good (4) or excellent (5), with only one student having a grade of satisfactory (3). ${ }^{2}$ These students are mainly motivated, although it is not always easy to activate them in class. Some of them still regularly take part in mathematics competitions and they attend group study sessions weekly.

\section{Methods of data collection}

The students participating in the experiment started by completing various psychological tests focusing on their communication skills, their attitude towards learning, their attitude towards working in groups and their attitude towards mathematics. They also took a mathematics pre-test, post-test and delayed test (Ambrus, 2004; Tóth, 2007), all of which were constructed so that the selected problems test the mathematical knowledge and thinking methods that are needed during the experiment.

Half of the lessons were recorded on video and the discussions of the different groups were also recorded with a voice recorder. During the lessons, the teacher observed the groups' work and the reaction of the individual students, and each student had a so-called "reflection book". As we have seen, one of the most important steps of problem solving is reflecting on both the solution and the strategy used. In order to record all of the ideas, thoughts and comments that might occur during the experiment, each student had a so-called "reflection book", a small exercise book in which they were instructed to take notes. These notes not only included mathematical ideas and ways of problem solving, but also personal feelings, reactions, etc. The students first described their working method in their own words, but in the discussions some heuristic strategies were named as well.

\section{Forming groups}

In order to form efficient groups, the following aspects had to be taken into consideration: a) friends in a group?; b) some students are difficult to work with; c) some students are less talkative; d) some students are tolerant, so can work with anyone, etc.

As stated above (Crabill, 1990), the optimal group contains four members. There were 16 students taking part in the research, so four groups of four were created. Each group was constituted so that it included a weaker student, a more able student, a quiet student and a more talkative student; moreover, "difficult" students were grouped with patient ones. The group settings were

2 In Hungary, we use a five-grade marking scale, in which 1 means fail and 5 means excellent achievement. 
changed once during the first part of the experiment. ${ }^{3}$ The reason for this was to give the students an opportunity to work with as many fellow students as possible. In order to achieve efficient, cooperative work, however, the group members needed time to get used to each other, so more frequent changes in the group settings were avoided.

\section{The problems}

Five curriculum-based problems were selected, derived from different fields of mathematics (algebra, geometry, number theory, combinatorics). ${ }^{4}$ As Hungarian textbooks contain hardly any open problems or investigations, these problems were either open problems already or they were chosen so that they could be "opened". Possible ways of extension were suggested either by the teacher or the students. Twelve 45-minute lessons were devoted to discussing these tasks. The main aim was to explore and discuss each problem in great detail, and if possible extend it as well, which is why two or three lessons were planned to be used for each problem. The present article describes the discussion of one of these problems in detail.

Since our plan was to examine the effect of the regular use of cooperative teaching techniques on the development of problem-solving skills, each of the aforementioned 12 lessons was planned with this method. Although the tasks might suggest otherwise, providing fun mathematics for the students was not the main aim of the experiment, which is why all of the problems are curriculum-based and develop mathematical competencies.

\section{The problem presented}

The problem presented in this article is an area investigation task. Students received the following figure:
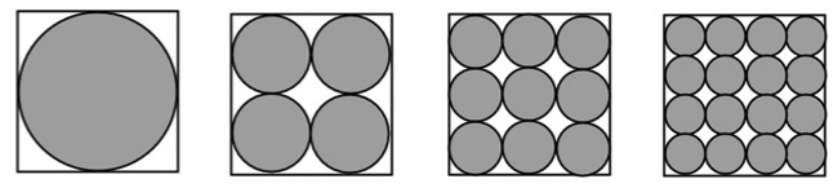

Problem: From a square measuring $60 \mathrm{~cm}$ by $60 \mathrm{~cm}$ we cut circles as you can see on the figure above. What percentage of the square is wasted? Do you recognise a pattern? Can you generalise your idea? Can you prove your conjecture for $\mathrm{n}$ circles?

3 The first part contained 12 lessons. See The problems.

4 List of problems: Appendix 
Extension: How could you modify the problem? Can you think of any other regular shapes that could be used?

\section{Lesson plan and experiences}

Firstly, it should be pointed out that by the time the students received this problem they had already had some experience in working in groups, so forming the groups went smoothly. Secondly, the detailed discussion of the whole problem took three consecutive 45-minute lessons. Solving and reflecting on the original problem was followed by the students' modification of the problem as well as the solution and discussion of part of this subsequent problem.

\section{Starter activity}

As a starter activity, the groups were given a worksheet on which they listed all of the mathematical knowledge - this could be a mathematical word or a formula - that they thought would be useful in solving the problem. One interesting point should mentioned in this regard: all of the groups noted down that they would use percentages during the solution, as this was mentioned in the statement of the problem, but in the end only one group actually worked out the percentage of wasted material, while the rest worked with fractions. Instead of using posters, the mathematical information that the groups had collected was written on the white board, which was divided into four parts. Each group had a section to write their formulae in. ${ }^{5}$ After the groups had finished collecting useful mathematical ideas, they sent one of their members to the white board to share the group's notes with the others. Each group had time to modify their notes on the basis of what was written on the board, and they then started solving the problem.

\section{Solving the original problem ${ }^{6}$}

To start with, the easiest part for the groups was to determine that the area of the wasted material is the same for all four arrangements. Admittedly, calculating the area of a square and some circles and doing some basic arithmetic should not be a challenge for a 16- or 17-year-old student, so it is no wonder that they completed this part of the task quite quickly and none of the groups needed extra help.

However, when I asked the groups: "How about n circles?", all of them said that the waste must be the same in that case too. I then asked them to prove their statement, in order to generalise what they had found. The reason for this is that students do not usually feel the need for proof, and have little 
experience with generalising let alone proving statements. Consequently, it was at this point that the students became puzzled. Nobody had any idea how to start, and therefore I had to provide some guidelines, some helping questions and comments (CBS, 2011), as follows:

- What can you say about the number of circles?

- What is the relationship between the number of circles and the length of the side of the square? Can you write an expression for the side length in terms of the number of circles?

- Can you write an expression for the area of the circles?

- $\quad$ Can you express the wasted area?

Since the working pace of the groups was different, this discussion took place four times.

Why did the students struggle with generalising their ideas? It could be that in everyday mathematics lessons, problem solving usually ends here: you do some calculations on the basis of the given data, you attain some results that seem correct, job done, you can go to the next exercise. It is therefore no wonder that when I encouraged the students to read the whole question again, and they realised that they had to find an answer in case of the nth figure, they looked a bit puzzled. After the groups received the aforementioned "helping questions", they were asked to continue working in pairs using the "Pairs Check" method.

The pairs were given some time to brainstorm ideas but were asked to continue the solution in the original groups. After some productive thinking and discussion, the groups came up with some seemingly different formulae for the amount of wasted material in the nth square. Although it was a lesson based on cooperative teaching methods, to ensure that everybody was on the right track an occasional whole-class discussion was unavoidable. In order to do this in an effective way, the white board was again divided into four sections, and after each group had worked out a formula for the nth square, the formulae were written in the different sections. Each formula was then interpreted with the help of the groups. In this discussion, the teacher led the students through their explanations with the help of questions.

The groups came up with four different formulae that were meant to express the same thing, so first of all we had to clarify how they had created these formulae and what the different parts meant. A speaker from each groups was therefore selected to explain their formula. It was not surprising that all of the formulae turned out to be equivalent and correct. After generalising the problem, the question arose as to whether the task could be modified to create a problem field (Pehkonen, 1997), and if so, how. 


\section{Modifying the problem}

Although the students came up with various ideas, due to a lack of time we settled on one that suggested replacing the square with an equilateral triangle and trying to arrange congruent circles inside it. At first, the students only had to work out the possible arrangements, as, in my experience, it often helps if they receive a task in easily understandable chunks.

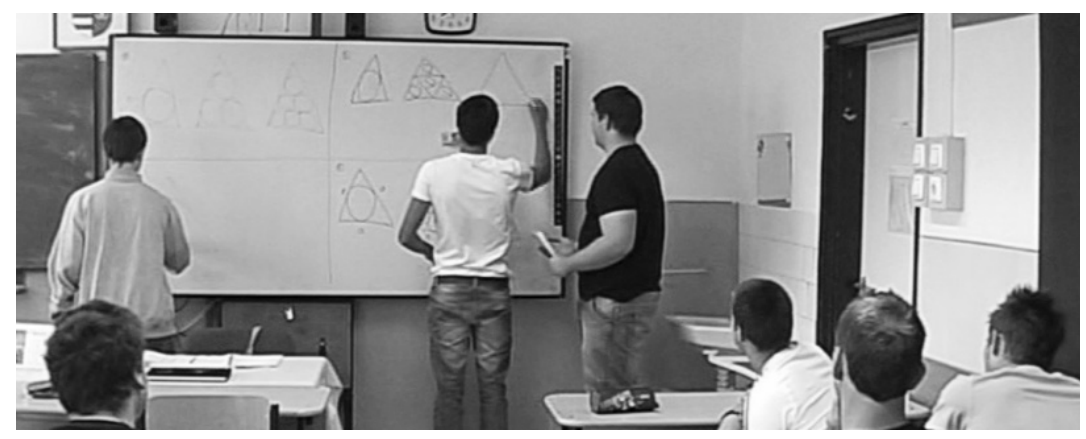

Figure. Students drawing their arrangements on the board.

\section{The new problem}

Now that we had some pictures to work with, the groups received the following questions regarding both arrangements (see picture above):

- How many congruent circles fit into each triangle? Do you notice a pattern?

- How many circles would be in the $\mathrm{n}^{\text {th }}$ triangle?

- If we cut out the circles, how much of the triangle would be wasted?

The students soon noticed that in the first arrangement the total number of circles can be calculated from the following pattern:
1
1,2
$1,2,3$
$1,2,3,4$

After each group had discovered this sequence, we paused for another whole-class discussion, as it was a perfect opportunity to introduce the concept of triangle numbers; furthermore, the students had noticed that discovering this pattern leads to yet another problem, i.e., how to find the sum of the first $\mathrm{n}$ natural numbers. ${ }^{7}$

Once the pattern of the circles was determined and the formula for the $n^{\text {th }}$ triangle number ${ }^{8}$ explained, the groups found a new obstacle. Clearly, this

7 At this stage, the students were neither familiar with the explicit definition of number sequences nor did they know the formula for the sum of the first $\mathrm{n}$ terms in a sequence.

8 The same as the sum of the first $\mathrm{n}$ natural numbers. 
time a new method was needed for deriving the radius of the circle that was inscribed the equilateral triangle. ${ }^{9}$ The groups therefore had to work together again using "Pairs Check". The same procedure as before was used. Following the pair work, the groups came together and compared their results, then the different ways of calculating the length of the radius were presented on the board divided into four sections.

Unfortunately, due to a lack of time, we were unable to proceed any further with the detailed analysis of the problem in class. The rest of the problem was therefore left to be discussed in group study sessions.

\section{Evaluation}

In general, the groups were able to work together quite effectively, as can be observed on the video recordings. The voice recordings provide further evidence that the communication in the different groups was efficient, although the students sometimes struggled to express their ideas with the correct mathematical terms. Even students who usually just sit and listen in class participated rather actively, as shy students were "forced" to communicate and express their ideas. There is one student in the class who is quite capable in mathematics but tends to display disruptive behaviour; however, in cooperative work he managed to control himself and contributed to the work of his team very well. It was also interesting to see that there was a so-called "silent group", in which the members restricted communication to the minimum necessary. Despite the fact that they did not talk as much, this group managed to proceed well with the solution of the task.

The voice recordings also demonstrate that students opened up and were braver than in previous lessons in terms of sharing their ideas with each other and asking questions. They did not mind being wrong or suggesting something that might sound unreasonable at first. Let us now review what the students said about cooperative learning.

\section{Students' comments}

"Working in groups is sometimes good, but sometimes I can't contribute to the discussions." K. A.

"It was helpful when K. D. had some ideas and I could carry on from his, but the behaviour of B. P. was often annoying." H. M.

"I learned a lot from my group mates." M. Sz.

9 Since the lessons were only 45 minutes long, we did not have an opportunity to check how to calculate the radii of the circles in the second, third, etc., arrangements. This was left for discussion in group study sessions. 
"I enjoyed working in groups but we shouldn't do it this often. Not every lesson.” P. R.

"It was easier to work together than alone, because we had people thinking differently and this helped a lot." K-M. M.

"Cooperative work brings the members of the groups closer, but I think frontal teaching is more effective." N. B.

"It could have been better if we had been allowed to choose who to work with." B. P.

\section{From the teacher's perspective}

Using cooperative teaching techniques changed my role as teacher. The bulk of the work was done before the lesson; planning cooperative lessons requires creativity from the teacher as well, which was sometimes challenging. In class, my task was simply to monitor the students and guide them towards the right solution. While my students were working on the given task, I was checking whether they were proceeding in the right direction, making sure that they did not misunderstand anything. If a group got stuck and the members could not help each other, it was my task to help them continue their work with useful comments or questions. This way of working gave me an opportunity to gain a better insight into how my students think, how they solve problems. I could help students who were slower while the others were busy working on their tasks.

Since the last phase of the experiment - completing the psychological questionnaires again and administering the delayed mathematics test - took place in June 2013, the complete analysis of the quantitative data is still in progress. In answering the research question, we must for now rely on the students' comments in their "reflection books", as well as the teacher's notes made during the lessons. Based on these two sources, we can say that cooperative learning:

- $\quad$ can be considered to be an effective tool for developing problem solving skills, as it (1) contributed to the development of students' individual thinking: as they became accustomed to cooperative work they required less and less assistance in solving problems; and (2) provided more opportunity for students to think creatively than frontal teaching: their "reflection books" show that they often came up with multiple solutions for a problem;

- $\quad$ should be used alongside and mixed with other methods: students' comments show that using cooperative techniques exclusively for an extended period of time is not the best approach. 


\section{Future work}

This experiment is far from completed. There is, of course, a massive amount of data to be analysed: the recordings of the lessons, the reflection books and the pre- and post-tests. In addition, this particular class continued working with cooperative structures once every two weeks and they then completed further psychological and mathematical questionnaires at the end of the school year, which provided further data to work with. Based on the experience of these 12 lessons, a similar experiment will also be planned for another class.

\section{Acknowledgements}

This research was supported by the European Union and the State of Hungary, co-financed by the European Social Fund, within the framework of TAMOP 4.2.4. A/2-11-1-2012-0001 "National Excellence Program".

\section{References}

Ambrus, A. (2004). Bevezetés a matematika didaktikába. (Introduction to Mathematical Didactics). Budapest: ELTE Eötvös kiadó.

Ambrus, G. (2000). "Nyitott” és “nyitható” feladatok a tanárképzésben és a matematikaoktatásban. [“Open” and "Openable” Problems in Teacher Training and Mathematics Education]. Matematika tanítása, $\operatorname{VIII(1),~7-15.~}$

Burns, M. (1990). Using Groups of Four. In N. Davidson (Ed.), Cooperative-learning in Mathematics (pp. 21-46). Boston: Addison-Wesley Publishing Company.

Capacity Building Series. (2011). Asking Effective Questions. Retrieved 13 January 2013 from http:// www.edu.gov.on.ca/eng/literacynumeracy/inspire/research/CBS_AskingEffectiveQuestions.pdf Crabill, C. D. (1990). Small-group Learning in the Secondary Mathematics Classroom. In N. Davidson (Ed.), Cooperative-learning in Mathematics (pp. 201-227). Boston: Addison-Wesley Publishing Company.

Dees, R. L. (1990). Cooperation in the Mathematics Classroom: A User’s Manual. In N. Davidson (Ed.), Cooperative-learning in Mathematics (pp. 160-200). Boston: Addison-Wesley Publishing Company. Fisher, R. (2005). Teaching Children to Think. Cheltenham: Nelson Thornes.

Gardner, M. (1988). Riddles of the Sphinx. Washington D. C.: The Mathematical Association of America.

Hähkiöniemi, M., Leppäaho, H., \& Francisco, J. (2012). Model for teacher assisted technology enriched open problem solving. In T. Bergqvist (Ed.), Learning Problem Solving and Learning Through Problem Solving, proceedings from the $13^{\text {th }}$ ProMath conference, September 2011 (pp. 30-43). Umeå: UMERC. 
Johnson, R. T., \& Johnson, D. W. (1994). An Overview of Cooperative Learning. In J. Thousand., A.

Villa, \& A. Nevin (Eds.), Creativity and Collaborative Learning. Baltimore: Brookes Press.

Johnson, D. W., \& Johnson, R. T. (2009). An Educational Psychology Success Story: Social

Interdependence Theory and Cooperative Learning. Educational Research, 38(5), 365-379.

Józsa, K., \& Székely, Gy. (2004). Kísérlet a kooperatív tanulás alkalmazására a matematika tanítása

során. [Experiment for Using Cooperative Learning in Teaching Mathematics]. Magyar pedagógia,

104(3), 339-362.

Kagan, S. (2003). A Brief History of Kagan Structures. Kagan Online Magazine. San Clemente, CA:

Kagan Publishing.

Kagan, S. (2004). Kooperatív tanulás. [Cooperative Learning]. Budapest: Önkonet.

Kagan, S., \& Kagan, M. (1998). Multiple Intelligences: the Complete MI Book. San Cemente, CA: Kagan Publishing.

Kilpatrick, J. (1987). Problem Formulating: Where do Good Problems Come From? In A. H.

Schoenfeld (Ed.), Cognitive Science and Mathematics Education. New Jersey: Lawrence Erlbaum

Associates Inc.

Kirkley, J. (2003). Principles for Teaching Problem Solving. Retrieved February 202012 from: http:// citeseerx.ist.psu.edu/viewdoc/downloaddoi=10.1.1.117.8503\&rep=rep1\&type $=$ pdf

Koshy, V. (2005). Action Research for Improving Practice. London: Paul Chapman Publishing. Lénárd, F. (1987). A problémamegoldó gondolkodás. [Problem Solving Thinking]. Budapest:

Akadémia kiadó.

Mayer, R. E., \& Hegarty, M. (1996). The Process of Understanding Mathematical Problems. In R. J. Sternberg \& T. Ben-Zeev (Eds.), The Nature of Mathematical Thinking. New Jersey: Lawrence Erlbaum Associates Inc. More Beads. Retrieved August 152012 from http://nrich.maths.org/2048 Pehkonen, E. (1997). Use of problem fields as a method for educational change. In E. Pehkonen (Ed.), Use of open-ended problems in mathematics classroom (pp. 73-84). Helsinki: University of Helsinki. Pehkonen, E. (1999). Open-ended Problems: A Method for an Educational Change. In International Symposium on Elementary Maths Teaching (SEMT 99). Prague: Charles University. Pólya, Gy. (1962). Mathematical Discovery. New York: John Wiley \& Sons Inc. Pólya, Gy. (1973). How to Solve it. New Jersey: Princeton University Press.

Slavin, R. E. (1996). Research for the Future. Research on Cooperative Learning and Achievement: What We Know, What We Need to Know. Contemporary Educational Psychology, 21, 43-69.

Schoenfeld, A. H. (1992). Learning to Think Mathematically: Problem Solving, Metacognition, and Sense-making in Mathematics. In D. Grouws (Ed.), Handbook for Research on Mathematics Teaching and Learning (pp. 334-370). New York: MacMillan.

Tóth, L. (2007). Pszichológiai vizsgálati módszerek a tanulók megismeréséhez. [Psychological Methods for Getting to Know the Students]. Debrecen: Pedellus.

Way, J. (s.d.). Problem Solving: Opening up Problems. Retrieved October 212013 from http://nrich. maths.org/2471

Zimmermann, B. (1986). From Problem Solving to Problem Finding in Mathematics Education. In 
P. Kupari (Ed.), Mathematics Education Research in Finland, Yearbook 1985 (pp. 81-103). Jyväskylä: Institute for Educational Research.

Zimmermann, B. (2009). "Open ended Problem Solving in Mathematics Instruction and some Perspectives on Research Questions” revisited - New Bricks from the Wall. In A. Ambrus \& É. Vásárhelyi (Eds.), Problem Solving in Mathematics Education, proceedings from the $11^{\text {th }}$ ProMath conference, September 2009 (pp. 143-157). Budapest: ELTE.

\section{Biographical note}

Krisztina BARCZI is a PhD student at the University of Debrecen in Hungary and a secondary school Mathematics teacher at Janos Neumann Secondary School where she has been teaching for 4 years. She started taking part in education related research as a university student (Krygowska Project of Professional Development of Teacher-Researchers) and continued her work in different British secondary schools as a Mathematics teacher where she carried out further research through the University of Cambridge (HertsCam Network) on motivating low achievers in Mathematics. Presently her field of interest is applying cooperative teaching techniques for mathematical problem solving. The article Applying cooperative techniques in teaching problem solving summarizes part of an action research related to this topic. 


\section{Appendix}

1. Matchstick game: Two players and 27 matchsticks are needed. The two players take turns and remove 1, 2 or 3 matchsticks. The winner is the one who removes the last matchstick. Task for the groups: to find a winning strategy for both players (Ambrus, 2004).

2. Number magic: In this problem field, the individual problems are related to simple number tricks that can be explained using number theory. For example: type the number 15,873 into your calculator. Select a number from 1 to 9 and multiply 15,873 by that number. Now multiply the product by 7 . What do you notice? Try with different digits. Can you explain what is going on? (Gardner, 1988).

3. Area investigation: From a square measuring $60 \mathrm{~cm} \times 60 \mathrm{~cm}$ we cut out circles as you can see on the figure. What percentage of the square is wasted in each case? Do you notice a pattern? Can you generalise your idea? Can you prove your conjecture for $\mathrm{n}$ circles?

4. More beads: Three beads are threaded on a circular wire and are coloured either red or blue. You repeat the following actions over and over again: between any two beads of the same colour place a red bead, and between any two beads of different colours put a blue bead, then remove the original beads. Discuss all of the possible outcomes. What happens when you do the same thing with 4, 5 or 6 beads? (nrich)

5. Primes and factors: This problem field contains algebraic problems that can be solved using factorisation, special products and other algebraic modifications. For example: Think of a two-digit number. Reverse its digits to obtain a new number and subtract the smaller number from the bigger one. Can you get a prime number as the result? Why/Why not? Can you prove that it is impossible to get a prime number? What if you use three digit numbers? Four digit numbers? N digit numbers? (nrich) 